\title{
Amphetamine-fuelled manic fornication. The case of Dean Cassady
}

\author{
Amir Jalbă, Adrian Brunello, Bogdan C. S. Pîrvu
}

Armin-Constantin Jalbă - MD., Psychiatry Resident, “Socola Institute of Psychiatry”, Iași, Romania

Adrian Brunello - PhD. Associate Professor, "Apollonia” University of Iași, Romania

Bogdan C. S. Pîrvu - MD., PhD. Clinical Psychiatrist, "Mavromati" Emergency Hospital, Botoșani, Romania

\begin{abstract}
We first provide a brief literature survey of amphetamine consumption in connection with sexual practices, and then focus on the special case of Dean Cassady who, while dying in his early forties, did not have the time to get into amphetamine psychosis, but had time enough to experience some fully-fledged mania. We will be exploring, rather more specifically, his increase in goal-directed activity (B6) coming complete with his risk-taking behaviour (B7), the emblematic beat character thus rising to mythological dimensions in what concerns his speed-fuelled fornication.
\end{abstract}

KEY WORDS:

Amphetamine consumption, Dean Cassady, beat, manic episodes, fornication.

\section{A BRIEF LITERATURE SURVEY}

The story of a 1970s ex-punkette (reproduced by the Deviants lead singer Mick Farren) goes that she and that night's "guy" were regular "speedfreaks" and, before their sex game began, he was "high as a kite" and she wasn't "much better" - what with "some kind of white powder" and lots of "vodka, first with juice and then with shots on their own." It thus took him "quite a while" to get "a hardon," but once the erection was there it stayed. He just "couldn't come," but "with the relentless determination of a goddamned speedfreak" he kept going and going, no matter what, killing him or her. At first "it was a turn-on" that he was able to keep up so steadily, but in time her frustration soared to the skies and she got this resentment she was "a little more than a means to an end" and perhaps she wasn't doing enough to "help him" - also, this "paranoia and anxiety" that all of this was "her own fault." She wrapped "her legs around him" and did her best, "changing position, playing with his balls, 
(1)

saying all kinds of dirty stuff to him," simply

"to get him off" or, "maybe to get him off her" - with "the whole business" becoming "a nightmare," the walls "closing in," the guy "turning into a thing, all frustration and gritted teeth," "slamming into her, and slamming into her." "It was insanity!" She was "dry," she was "sore," and she was getting "damned fed up with it all," now using "all her strength to push him off her," himself looking "fucking crazy," making "this weird noise somewhere between a sigh and groan," groaning and rolling "over on his side with his back to her," jerking himself off, "angry, almost violent," herself grabbing her clothes, leaving and hiding in the bathroom. Her unhappiness was still there in a few days' time, in the "counter-story," with a boy "speeding out of his mind," and meaning "to fuck so hard," only that "he just couldn't get it up" though she again did her best "sucking him and playing with his damn thing forever." It seems that "having sex on speed" is pretty much "impersonal," the guy wishing "to stick his dick in the woman," never giving "a damn otherwise": "it's always about you, and the other person is just there for the ride" or, to put it short, it's the narcissist's way! (1)

A study of 29 Stockholm convicts, with 27 having had sexual activity while on amphetamine, with 23 reporting to have been more sexually excited, with 21 reporting to have experienced intensified orgasms, with 23 reporting to have had prolonged intercourse, with 6 having more than 10 partners during the last 3 years, with only 3 having had a condom during their last intercourse with a casual partner (2); another study of 115 amphetamine users, with $51 \%$ of the male sample and $20 \%$ of the female sample reporting to have had sex as their preferred activity while actually on amphetamine (3); still another study of 301 regular amphetamine users $(2 / 3$ of the subjects injecting the drug) with the subjects having been associated with paid sex, quite a number of sexual partners and higher levels of psychopathology, while the male cohort was 1.8 times more likely to do so (4) - all of the three studies were to confirm the expunkette's story in broad lines, that one could basically find gender differences in the physiological and psychological approach to sex-on-amphetamine.

A 35-voiced interview (5) was to go still further, the heterogeneous group of interviewers revealing differences in the impact of amphetamine that are provided by "personal experience and culturallydetermined expectations." The drug was expected to "increase sexual desire and enhance sexual experience" and, indeed, at least at the beginning it seemed to facilitate "sexual experimentation" in its positive dimensions but gradually it changed into something like a succession of manic episodes, with "marathon sex being an important component."

To cut a long story short, "even when one manipulates the sexual act with amphetamine," the strong individuality going into human sexuality still remains. The overall experience of "mixing amphetamine and sex," while changing in "a negative direction over time," appears to be a result of "the interaction between amphetamine, the relational setting and the sexual script of the individual." The story to come will be a good case in point.

\section{THE CASE OF DEAN CASSADY}

To Neal Cassady sex was "the one and only holy and important thing in life." Now he had just dispatched his guest to the kitchen, supposedly to make coffee, but actually for him to proceed with his "love problems." (R: 4) It was not that he hardly respected his 
r s

guest, or that he didn't care "one way or the other" especially when "eager for bread and love," but "so long's [he] could get that lil ole gal with that lil sumpin down there tween her legs, boy" ... (R:10) For some time now, in Denver, he was "making love to two girls at the same time, they being [LuAnne], his first wife, who waited for him in a hotel room, and [Carolyn], a new girl who waited for him in a hotel room." Between the two of them he rushed to his friends for their "unfinished business," getting benzedrine and communicating "with absolute honesty and absolute completeness everything" on their minds, while sitting on the bed, "crosslegged facing each other." (R: 38) The schedule, because there was "always a schedule" in Neal's life, was this: while [Allen Ginsberg] was coming off work, changing and dressing, he was balling LuAnne "at the hotel." "At one sharp" he rushed from LuAnne to Carolyn "of course neither one of them [knew] what's going on" - and banged her once again, giving Allen "time to arrive at one-thirty." Then he came out with Allen - "first he [had] to beg with Carolyn, [who'd] already started hating [Allen]" - and they came here "to talk till six," no later because he was "pressed for time." Then "at six" he went back to LuAnne because she insisted on banging. She said she loved him, and so did Carolyn, and he couldn't help doing her favours. How did he ever come on her, for God's sake? One of his friends, a poolhall boy, found her in a bar and took her to a hotel; "pride taking over his sense, he invited the whole gang to come up and see her." Now, "everybody sat around talking with her," Neal did "nothing but look out the window." Then when everybody left, "he merely looked at her," pointed at his wrist, made the sign 'four' ("meaning he'd be back at four"), and went out. At three "the door was locked to the poolhall boy, at four it was opened to Neal." The two of them were now haggling in a rooming-house and, when
Jack Kerouac knocked, he opened the door "stark naked," Carolyn "on the bed, one beautiful creamy thigh covered with black lace," looking up with "mild wonder." "Why, Jack!" said Neal - yes, of course, you've arrived - you old sonumbitch you finally got on that old road. Well, now, look here - we must - yes, yes, at once - we must, we really must!" And swirling on Carolyn, "[Jack] is here, this is my old buddy from New York, this is his first night in Denver and it's absolutely necessary for me to take him out and fix him up with a girl." It was "exactly one-fourteen," and he promised he'd be back at "exactly three-fourteen," for their "hour of reverie together, real sweet reverie, darling." Remember "not three but three-fourteen." Are we straight in the deepest and most wonderful depths of our souls, dear darling?" Off the two guys rushed into the night, Allen joining them in an alley. "Jack," said Neal, "I have just the girl waiting for you at this very minute - if she's off duty" ... "a waitress, fine chick, slightly hung-up on a few sexual difficulties, which I've tried to straighten up, and I think you can manage" while "I've just got to get into her sister Mary tonight." (R:40) He did it, and when "three o'clock came, he rushed off for his hour of reverie" with Carolyn. As for the date with LuAnne, he insisted and found her in a hotel, "up in Denver." They had "ten hours of wild lovemaking," and decided on the spot to stick, "cause she was "the only girl he ever really loved." He was "sick with regret when he saw her face again, and, as of yore, he pleaded and begged at her knees for the joy of her being." And "she understood him; she stroked his hair; she knew he was mad." (R: 101) A few hours later, up in town, "he leaped off and rushed to see a colored girl that just then passed outside the station." "Dig her," he shouted, standing with "limp finger pointed, fingering himself with a goofy smile," "that little gone black lovely. Ah! Hmm!” (R: 104) 
.

Still later he stood "googing around with a towel" and necking with LuAnne "among the pots and pans," until they withdrew "to a dark corner in the pantry" ... (R: 106) All through the New Year's weekend, going on for "three days and three nights," Neal was having "his kicks"; he put on "a jazz record," grabbed LuAnne, held her tight and "bounced against her with the beat of the music," while she was bouncing "right back" in "a real love dance," in the middle of "a huge gang." (R: 113) On the way to New Orleans, in the car Neal suddenly became tender, asking Jack and LuAnne to admit that "everything" was fine and there was "no need in the world to worry," and in fact they should realize they were not "really worried about anything" as long as they were "all together" - all the while "steering while kissing and fooling around" with LuAnne. "Oh man, what kicks!" he yelled, "Now honey, listen really, you know that I'm hotrock capable of everything at the same time and I have unlimited energy - now in San Francisco we must go on living together. I know just the place for you - at the end of the regular chain-gang run - I'll be home just a cut-hair less than every two days and for twelve hours, darling. Meanwhile I'll go right on living [with my wife] like nothin, see, she won't know. We can work it, we've done it before." (R: 122) But at dusk, while coming into "the humming streets of New Orleans," he yelled with his face out the window, sniffing. "Ah! God! Life!" He darted the car and looked "in every direction for girls." "Oh, I love, love, love women! I think women are wonderful! I love women!" He spat "out the window," groaned and clutched his head. Great beads of sweat fell from his forehead "from pure excitement and exhaustion.” (R: 127) He giggled "maniacally," rubbed his fly, stuck his finger in LuAnne's dress, slurped up her knee, frothed at the mouth," and said "Darling, you know and I know that everything is straight between us at last beyond the furthest abstract definition in metaphysical terms or any terms you want to specify or sweetly impose or harken back ..." (R:141) She was watching him "as she had watched him clear across the country and back, out of the corner of her eye" - "with a sullen, sad air," as if "she wanted to cut off his head and hide it in her closet, an envious and rueful love of him so amazingly himself, all raging and sniffy and crazy-wayed," "a love she knew would never bear fruit" because "she knew he was too mad." Neal, on the other hand, was positive she was "a whore" and "a pathological liar." (R: 148) And "the whore ran off" at long last (R: 158), leaving him with a sense of freedom, though. He lost no time and talked "a waitress in a luncheonette" into driving in his Cadillac and made it with her, "in nothing flat, in a parking lot in broad daylight." (R: 204) And he made it with a teenager who "blushed and blushed" (R: 206), with "a strange middle-aged colored woman" "flapping her hips" and butt (R: 216), with "that woman in that window up there, just looking down with her big breasts hanging from her nightgown, big wide eyes" (R: 217) ...with this and that woman, in a neverending array.

\section{DISCUSSIONS AND CONCLUSIONS}

We now feel compelled to ask the legitimate question about the "true-to-life" quality of Neal Cassady's sexual exploits. If they are "there" as mere products of Jack Kerouac's imagination, are they worth reproducing? Our answer is that even so, even if products of fantasy, they have their significant value as psychopathological documents - simply because the artistic personality is not 

necessarily less trustworthy than the medical personality. On the contrary, free as they are from factual constraints, writers sometimes deliver their cases in their textbook version, i.e. by the book.

Any doubts aside though, and some exaggerations aside to boot, the Neal Cassady in On the road seems to be the next best thing to the real Neal Cassady who sent Jack Kerouac, in December 1950, a long letter describing his short-time affair with Cherry Mary, how the mother of the woman for whom she was baby-sitting showed up, and he was forced to hide in the bathroom, "nude, no clothes, and all exits blocked," how Mary tried to divert the mother while he discovered his task was to, "as quietly as a mouse," remove "all the yearslong collection of rich people's bath knickknacks that blocked the room's only window," then "impossible though it looked," climb "up the tub to it and with a fingernail pry loose the outside screen" - the window having "four panes of glass 6 inches long and 4 inches wide," forming a "rectangle of about 12 inches or 13 inches high and 8 inches or 9 inches across, difficult to squeeze through at best" but, when opened, splitting "the panes of glass down the middle" and making "two windows," simply because it was "hooked to its frame by a single metal bar in direct centre!" And then he could hardly reach to work on the screen - since the window opened outward - but he pushed and made "a hellova noise," splitting the screen "enough to open the window." Now "the impossible compressing" of his own frame "for the squeeze." He thought if he could get his head through, he could make it; he was just able to, "by bending the tough metal bar" ... and of course, he almost tore off his "pride-and-joy" as he wiggled out "into the cold November air...." (Charters 1991: XVII)

The conclusion then comes forth in a rather straightforward manner. Neal Cassady's sex exploits might well be read to the letter, and they are indeed indicative of his manic fornication, also responsible for his risk-taking behaviour, fuelled by the amphetamine consumption.

\section{ACKNOWLEDGEMENTS AND DISCLOSURES}

The authors declare that they have no potential conflicts of interest to disclose.

\section{REFERENCES}

1. Farren M (2010) Speed-Speed-Speedfreak. London: Feral House.

2. Köll KI (1992) Effects of amphetamine on sexual behaviour of male i.v. users in Stockholm. AIDS Education and Prevention 4(1): 6-17.

3. Köll KI, Nilsome A (1995) Preference for sex on amphetamine: a marker for HIV risk behaviour among male intravenous amphetamine users in Stockholm. AIDS Care 7(2): 171-188.

4. Darke S, Ross J, Cohen J, Hando J, Hall W (1995) Injecting and sexual risk-taking behaviour among regular amphetamine users. AIDS Care 7(1): 19-26.

5. Skörner A, Svensson B (2017) Amphetamine use and sexual practices. Nordic Studies on Alcohol and Drugs. 30(5): 403-423.

6. Kerouac J (1955/1991) On the Road. London: Penguin (qtd. as R).

7. Charters A (1991) Introduction to On the Road. London: Penguin. VII-XIX.

\section{Correspondence \\ Adrian Brunello, \\ PhD. Associate Professor, “Apollonia” University of Iași, Romania, adrian_brunello@yahoo.com}

